\title{
Institutional infrastructure and economic performance: dynamic panel data evidence
}

\begin{abstract}
This paper attempts to empirically investigate the link between institutional quality and economic performance in a group of 72 countries during 1980ï 2001, using dynamic panel data analysis. Five institutional indicators that represent the overall institutional infrastructures of an economy are employed, namely corruption, rule of law, bureaucracy, repudiation of contracts and risk of expropriation. The empirical results demonstrate that institutionsôvariables are statistically significant determinants of economic performance. The findings also suggest that the effects of institutional quality vary according to the level of economic development, where institutions are more responsive in the low-income and middle-income countries. In terms of specific effect of institutional development, the results reveal that the higher level of rule of law is most potent in delivering long-run economic benefits.
\end{abstract}

Keyword: Institutions; Laws; Regulations; Economic growth; Dynamic panel data analysis 